\title{
7
}

\section{Micro and Nano Corrosion in Steel Cans Used in the Seafood Industry}

\author{
Gustavo Lopez Badilla ${ }^{1}$, \\ Benjamin Valdez Salas ${ }^{2}$ and Michael Schorr Wiener ${ }^{2}$ \\ ${ }^{1}$ UNIVER, Plantel Oriente, Mexicali, Baja California \\ ${ }^{2}$ Instituto de Ingenieria, Departamento de Materiales, Minerales y Corrosion, \\ Universidad Autonoma de Baja California \\ Mexico
}

\section{Introduction}

The use of metal containers for food preservation comes from the early nineteenth century, has been important in the food industry. This type of packaging was developed to improve food preservation, which were stored in glass jars, manufactured for the French army at the time of Napoleon Bonaparte (XVIII century), but were very fragile and difficult to handle in battlefields, so it was decided the produce metal containers (Brody et al, 2008). Peter Durand invented the metallic cans in1810 to improve the packaging of food. In 1903 the English company Cob Preserving, made studies to develop coatings and prevent internal and external corrosion of the cans and maintain the nutritional properties of food (Brody, 2001). Currently, the cans are made from steel sheets treated with electrolytic processes for depositing tin. In addition, a variety of plastic coatings used to protect steel from corrosion and produce the adequate brightness for printing legends on the outside of the metallic cans (Doyle, 2006). This type of metal containers does not affect the taste and smell of the product; the insulator between the food and the steel, is non-toxic and avoid the deterioration of the food. The differences between metal and glass containers, as well as the negative effects that cause damage to the environment and human health are presented in Table 1.

The wide use of steel packaging in the food industry, from their initial experimental process, has been very supportive to keep food in good conditions, with advantages over other materials such as glass, ceramics, iron and tin. The mechanical and physicochemical properties of steel help in its use for quick and easy manufacturing process (Brown, 2003). At present, exist a wide variety of foods conserved in steel cans, but in harsh environments, they corrode. Aluminum is used due to its better resistance to corrosion, but is more expensive. With metal packaging, the food reaches to the most remote places of the planet, and its stays for longer times without losing its nutritional properties, established and regulated for health standards by the Mexican Official Standards (NOM). The difference between using metal cans to glass (Table 1) indicate greater advantages for steel cans (Finkenzeller, 2003). In coastal areas, where some food companies operate, using steel cans, three types of deterioration are detected: atmospheric corrosion, filiform corrosion and microbiological corrosion. Even with the implementation of techniques and methods of 
protection and use of metal and plastic coatings, corrosion is still generated, being lower with the use of plastics (Lange et al, 2003). Variaitons of humidity and temperature deteriorate steel cans (Table2).

\subsection{Steel}

Steel is the most used metal in industrial plants, for its mechanical and thermal properties, and manufacturing facility. It is an alloy of iron and carbon. Steel manufacturing is a key part of the Mexican economy. Altos Hornos is the largest company in Mexico, with a production of more than 3,000000 tons per year, located in Monclova, Coahuila, near the U.S. border (AHMSA, 2010). Steel is used in the food industry, especially in the packaging of sardines and tuna (Lord, 2008).

\begin{tabular}{|c|c|c|c|}
\hline \multicolumn{2}{|c|}{$\begin{array}{c}\text { PROPERTIES AND } \\
\text { UNPROPERTIES }\end{array}$} & \multicolumn{2}{|c|}{ NEGATIVE EFFCTS } \\
\hline METAL & GLASS & METÁL & GLASS \\
\hline $\begin{array}{l}\text { Resist the } \\
\text { irregular } \\
\text { handling and } \\
\text { transport }\end{array}$ & $\begin{array}{l}\text { Fragile and easily } \\
\text { broken }\end{array}$ & $\begin{array}{c}\text { Generation of filiform } \\
\text { and microbiological } \\
\text { corrosion }\end{array}$ & Cause spots of black color \\
\hline $\begin{array}{l}\text { Hermetically } \\
\text { sealed }\end{array}$ & $\begin{array}{l}\text { Not sealed; air } \\
\text { enters }\end{array}$ & $\begin{array}{l}\text { Bad sealed, creates } \\
\text { rancidity by } \\
\text { microbiological } \\
\text { corrosion } \\
\end{array}$ & $\begin{array}{c}\text { High percentage of } \\
\text { microorganisms by poor } \\
\text { seal }\end{array}$ \\
\hline $\begin{array}{l}\text { Good shelf life } \\
\text { without } \\
\text { refrigeration at } \\
\text { room } \\
\text { temperature }\end{array}$ & $\begin{array}{l}\text { Necessity of } \\
\text { refrigeration of } \\
\text { marine food }\end{array}$ & $\begin{array}{c}\text { At warm and cold } \\
\text { temperatures, foods } \\
\text { lose their nutritional } \\
\text { properties }\end{array}$ & $\begin{array}{l}\text { At warm and cold } \\
\text { temperatures, foods lose } \\
\text { their nutritional properties }\end{array}$ \\
\hline $\begin{array}{l}\text { Accessibility } \\
\text { manufacture }\end{array}$ & $\begin{array}{l}\text { Manufacturing } \\
\text { process complex } \\
\text { by its fragility }\end{array}$ & $\begin{array}{l}\text { By bad handling and } \\
\text { the internal } \\
\text { deterioration of the } \\
\text { coating, generates } \\
\text { filiform corrosion }\end{array}$ & $\begin{array}{l}\text { Cover deformation } \\
\text { generates gas food } \\
\text { deterioration }\end{array}$ \\
\hline $\begin{array}{l}\text { No frequent } \\
\text { supervision }\end{array}$ & $\begin{array}{c}\text { Frequent } \\
\text { supervision }\end{array}$ & $\begin{array}{c}\text { Susceptible to } \\
\text { atmospheric corrosion } \\
\text { in indoor and outdoor } \\
\text { environments }\end{array}$ & $\begin{array}{l}\text { Broken pieces of glass are } \\
\text { mixed with food, } \\
\text { generating health damage }\end{array}$ \\
\hline Easy recycling & $\begin{array}{l}\text { Difficult to } \\
\text { recycle }\end{array}$ & $\begin{array}{c}\text { Sterilization time is } 20 \\
\text { minutes }\end{array}$ & $\begin{array}{l}\text { In sterilizing process, glass } \\
\text { cans remains in hot water } \\
\text { for } 10 \text { to } 15 \text { minutes and can } \\
\text { generate bacteria }\end{array}$ \\
\hline
\end{tabular}

Table 1. Differences between metallic cans and glass containers in the food industry and their effect on health and environment 


\subsection{Metallic cans}

The steel cans consist of two parts: body and ring or three parts: body, joint and ring (Figures $1 \mathrm{a}$ and $1 \mathrm{~b}$ ).

When a steel can is not properly sealed, it is damaged by drastic variations of humidity and temperature creating microorganisms, which cause an injury on the health of consumers (Cooksey, 2005). Every day millions of cans are produced, the companies express their interest in research studies to improve their designs. There are two main types of steel cans: tin plated and plastic coated. Plastic coatings have good resistance to compression, and the resistance to corrosion is better than the tin plate. Since the oxide layer that forms on the container surface is not completely inert, the container should be covered internally with a health compatible coating (Nachay, 2007).

\begin{tabular}{|c|c|c|c|}
\hline \multirow[t]{2}{*}{ Corrosion } & \multirow{2}{*}{$\begin{array}{l}\text { Climatic } \\
\text { factors }\end{array}$} & \multicolumn{2}{|c|}{ Coatings } \\
\hline & & Metallic & Plastic \\
\hline $\begin{array}{c}\text { Atmospheric } \\
\text { External }\end{array}$ & $\begin{array}{l}\text { High levels of } \\
\text { humidity and } \\
\text { temperature }\end{array}$ & $\begin{array}{l}\text { In aggressive environments, is } \\
\text { generated external and } \\
\text { internal damage of steel cans }\end{array}$ & $\begin{array}{c}\text { Originates stains and } \\
\text { bad appearance } \\
\text { without damage }\end{array}$ \\
\hline $\begin{array}{l}\text { Filiform } \\
\text { Internal }\end{array}$ & $\begin{array}{l}\text { Low levels of } \\
\text { humidity }\end{array}$ & $\begin{array}{l}\text { In harsh environments, are } \\
\text { generated cracks under the } \\
\text { coatings and, is formed the } \\
\text { filiform corrosion }\end{array}$ & $\begin{array}{l}\text { No formation of cracks } \\
\text { in coatings as in the } \\
\text { steel cans }\end{array}$ \\
\hline $\begin{array}{l}\text { Microbiological } \\
\text { Internal } \\
\end{array}$ & $\begin{array}{l}\text { High levels of } \\
\text { humidity }\end{array}$ & $\begin{array}{c}\text { Dense black spots are formed } \\
\text { by OH- and rancidity }\end{array}$ & Isolated black spots \\
\hline
\end{tabular}

Table 2. Corrosion types in coated metallic cans used in the food industry

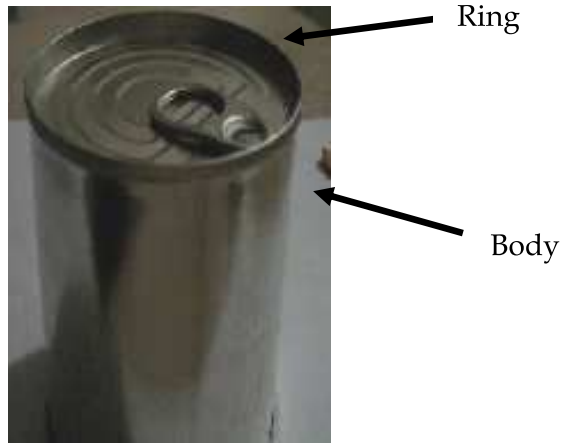

(a)

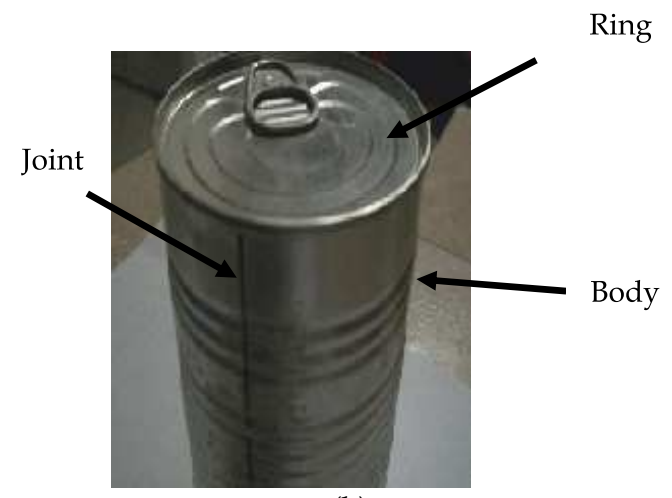

(b)

Fig. 1. (a) Aluminum cans without seams, in two parts: ring and body (b) Steel cans with seams: body, joint and rings

\subsection{Production stages}

The manufacture stages in a food industry are shown in Figure 2 (Avella, 2005):

Washing: Cans are cleaned thoroughly to remove the bacteria that could alter the food nutritional value. 
Blanching: The product is subjected to hot water immersion to remove the enzymes that produce food darkening and the microorganisms that cause rancidity.

Preparation: Before placing food in the can the non-consumable parts of the sardine and tuna are removed, then the ingredients to prepare the food in accordance with the consumption requirements are added.

Packaging: The food is placed in the can, adding preservatives such as vinegar, syrup, salt and others to obtain the desired flavor.

Air removal: The can pass through a steam tunnel at $70^{\circ} \mathrm{C}$, to avoid bad taste and odor.

Sealing: by soldering or with seams.

Sterilization: It is of great importance for the full elimination of microorganisms that might be left over from the previous stages, when the can is treated at temperatures of $120^{\circ} \mathrm{C}$.

Cooling. Once sterilized the cans are cooled under running cold water or cold water immersion, from the outside without affecting the food quality.

Labeling. On the can label are placed legends with product ingredients, expiration dates and lot numbers of production.

Packaging, is made to organize the food steel cans in boxes.

Food technology specialists considers, that an adequate manufacturing process of canned foods, helps to keep certain products up to several months and years, as the case of milk powder to nine months, some vegetables and meat foods two and up to five years. A diagram summarizing all these stages is displayed in Figure 2.

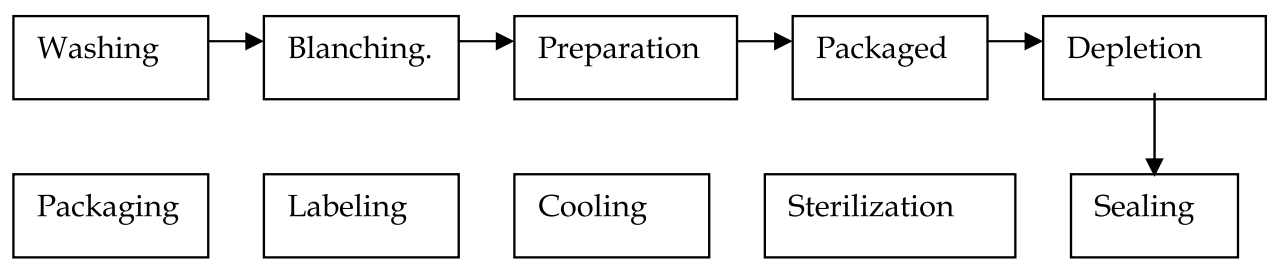

Fig. 2. Manufacturing steps in a food industry.

\subsection{Sea food industry in Mexico}

The main coastal cities in Mexico, with installed companies that fabricate metallic cans for sardines and tuna conservation are Acapulco, Guerrero, Ciudad del Cabo in the State of Baja California Sur; Ensenada, Baja California, Campeche, Campeche, Mazatlan, Sinaloa, Veracruz, Veracruz (Bancomext, 2010). The sardine is a blue fish with good source of omega-3, helping to lower cholesterol and triglycerides, and increase blood flow, decreasing the risk of atherosclerosis and thrombosis. Due to these nutrition properties, its widely consumed in Mexico; it contains vitamins B12, niacin and B1, using its energy nutrients (carbohydrates, fats and proteins) as a good diet. This food is important in the biological processes for formation of red blood cells, synthesis of genetic material and production of sex hormones. Tuna is an excellent food with high biological value protein, vitamins and minerals. It has minerals such as phosphorus, potassium, iron, magnesium and sodium and vitamins A, D, B, B3 and B12, which are beneficial for the care of the eyes and also provides folic acid to pregnant women. Fat rich in omega-3, is ideal for people who suffer from cardiovascular disease (FAO, 2010). 


\subsection{Atmospheric corrosion}

Atmospheric corrosion is an electrochemical phenomenon that occurs in the wet film formed on metal surfaces by climatic factors (Lopez et al, 2011, AHRAE, 1999). One factor that determines the intensity of damage in metals exposed to atmosphere is the corrosive chemical composition in the environments. The sulphur oxides ( $\mathrm{SO}_{\mathrm{x}}$ ), nitrogen oxides $(\mathrm{NOx})$, carbon oxide $(\mathrm{CO})$ and sodium chloride $(\mathrm{NaCl})$ that generates chloride ions $(\mathrm{Cl}-)$, are the most common corrosive agents. The $\mathrm{NaCl}$ enters to the atmosphere from the sea; $\mathrm{SO}_{\mathrm{X}}$, $\mathrm{NO}_{X}$ and $\mathrm{CO}$, is emitted by traffic vehicle. The joint action of the causes of pollution and weather determine the intensity and nature of corrosion processes, acting simultaneously, and increasing their effects. It is also important to mention other factors such as exposure conditions, the metal composition and properties of oxide formed, which combined, have an influence on the corrosion phenomena (Lopez, 2008). The most important atmospheric feature that is directly related to the corrosion process is moisture, which is the source of electrolyte required in the electrochemical process. In spite of existing corrosion prevention and protection systems as well as application of coatings in steel cans the corrosion control, is not easy in specific climatic regions, especially in marine regions. Ensenada which is a marine region of Mexico on the Pacific Ocean has a marine climate with cold winter mornings around $5{ }^{\circ} \mathrm{C}$ and in summer $35^{\circ} \mathrm{C}$. Relative humidity (RH) is around $20 \%$ to $80 \%$. The main climate factors analyzed were humidity, temperature and wind to determine the time of wetness (TOW) and the periods of formation of thin films of $\mathrm{SO}_{\mathrm{X}}$ and $\mathrm{Cl}^{-}$which were analyzed to determine the corrosivity levels (CL) in outdoors and indoors of seafood industry plants (Lopez et al, 2010).

\subsection{Corrosion of steel cans}

Corrosion of tinplate for food packaging is an electrochemical process that deteriorates the metallic surfaces (Ibars et al, 1992). The layer of tin provides a discontinuous structure, due to their porosity and mechanical damage or defects resulting from handling the can. The lack of continuity of the tin layer allows the food, product to be in contact with the various constituents of the steel, with the consequent formation of galvanic cells, inside of the cans. The presence of solder alloy used in the conventional container side seam is a further element in the formation of galvanic cells. Corrosion of tin plate for acidic food produces the dissolution of tin and hydrogen gas formation resulting from the cathodic reaction that accumulate in the cans. At present, the problems arising from the simultaneous presence of an aggressive environment, mechanical stress and localized corrosion (pitting) are too frequent (CGB, 2007).

\subsection{Coatings}

The food in steel can is protected by a metallic or plastic coating regulated by the FDA (Food Drugs Administration, USA) that does not generate any health problems in consumers (Weiss et al, 2006). The coating is adhered on the metal plate and its function is due to three main features:

- Thermal and chemical resistance assures the protection of the steel surface when a food produces a chemical attack by rancidity, changing the food taste.

- Adherence. The coating is easily attached to the inside can surface.

- Flexibility. Resistance to mechanical operations that modify the structure of the can, in the manufacturing process, such as molding shapes and bad handling. 
Currently, new materials and coatings are analyzed to fit them to food variety, beverages and other canned products (Table 3). The coatings used in the food industry are organosol type, with high solids content, creating dry films with thickness 10 to $14 \mathrm{~g} / \mathrm{m}^{2}$, for manufacturing or recycling, allowing large deformation (Soroka, 2002). To improve the strength of steel, two layers of epoxy-phenolic are applied, in the organosol film. If the food suffers decomposition, it generates deformation in the can (Yam et al, 2005). Coatings are applied on the cans on the inside and outside. Since the early twentieth century, coatings manufacturers have supported the food and beverage industries, using oleoresins resins, phenolic and later in 1935, was applied vinyl coating in the beer cans. Later comes the epoxy-phenolic coatings, organosoles, acrylic and polyester (Ray, 2006).

\begin{tabular}{|c|c|}
\hline \multicolumn{2}{|c|}{ CLASIFICACTION } \\
\hline COATINGS & DEFINITION \\
\hline $\begin{array}{c}\text { Protection in indoors of } \\
\text { cans }\end{array}$ & They are in contact with the packaged product and are called \\
"health coatings"
\end{tabular}

Table 3. Coatings used in the food industry 


\section{Materials and methods}

\subsection{Climate factors}

The climate is composed of several parameters; RH and temperature are the most important factors in the damage of steel cans. Scientists that analyze the atmospheric corrosion, consider that the grade of deterioration of steel cans is due to the drastic changes in the humidity and temperature in certain times of the year, as expressed in ISO 9223 (ISO 9223, 1992). Managers and technicians of companies and members of health institutions in Mexico are concerned in some periods of the year, by the quality of seafood contained in steel cans (Moncmanova; 2007).

\subsection{Corrosion testing}

Pieces of steel rolls were prepared for corrosion testing simulating steel cans, which were exposed at indoor conditions of seafood plants for periods of one, three, six and twelve months in Ensenada, following the ASTM standards G 1, G 4, G 31 (ASTM, 2000). The results were correlated with $\mathrm{RH}, \mathrm{TOW}$ and temperature parameters. The concentration levels of $\mathrm{SO}_{\mathrm{x}}$ and $\mathrm{Cl}^{-}$were evaluated with the sulfatation technique plate (SPT) and wet candle method (WCM), (ASTM G 91-97, 2010; ASTM G140-02, 2008). The industrial plants of seafood in this city are located at distances at $1 \mathrm{~km}$ to 10 from the sea shore. Steel plates used to fabricate steel cans with dimensions of $3 \mathrm{~cm} . X 2 \mathrm{~cm}$. and $0.5 \mathrm{~cm}$ of width, were cleaned by immersion in an isopropyl alcohol ultrasound bath for 15 minutes (ISO 11844-1, ISO 11844-2, Lopez et al, 2008). Immediately after cleaning the steel probes were placed in sealed plastic bags, ready to be installed in the test indoor and outdoor sites. After each exposure period the steel specimens were removed, cleaned and weighed to obtain the weight loss and to calculate the corrosion rate (CR).

\subsection{Examination techniques}

The corrosion products morphology was examined by the scanning electron microscope (SEM) and the Auger Electron Spectroscopy (AES) techniques.

- SEM. Used to determine the morphology of the corrosion products formed by chemical agents that react with the steel internal an external surface. The SEM technique produces very high-resolution images of a sample surface. A wide range of magnifications is possible, from about 10 times to more than 500,000 times. The SEM model SSX-550 was used; revealing details less than $3.5 \mathrm{~nm}$, in size from 20 to 300,000 magnifications and $0.5 \mathrm{~V}$ to $30 \mathrm{kV}$ by step.

- $\quad$ AES. It determines the chemical composition of elements and compounds in the steel cans and rolls, and analyzes the air pollutants deposited on the steel. With this technique we knew in detail, quickly and with a good precision, the structural form and location of corrosion at surface level which determined the type of corrosion (Clark,et al, 2006). AES analysis was performed in Bruker Quantax and ESCA / SAM 560 models, and the bombarding were obtained when samples with a beam of electrons with energy of $5 \mathrm{keV}$. We made a clean surface of steel specimens analyzed with an ion beam with energy $\mathrm{Ar}+5 \mathrm{keV}$ and current density of $0.3 \mathrm{uA} / \mathrm{cm}^{3}$ to remove $\mathrm{CO}_{2}$ from the atmosphere (Asami et al, 1997). The sputtering process indicates the type of film formed on the metallic surface of steel and the corrosion on separated points such as pitting corrosion. 


\subsection{Numerical analysis}

A mathematical correlation was made applying MatLab software to determine the CL in indoors of seafood industry in Ensenada in summer and winter (Duncan et al, 2005). With this simulation we find out the deterioration grade of steel probes, correlating the climate factors (humidity and temperature) and air pollutants (CO, $\mathrm{NOx}$ and $\mathrm{SOx}$ ), with the corrosion rate (CR).

\section{Results}

The generation of corrosion in steel cans is promoted by the formation of the thin film of corrosion products in their surface and the exposition of chlorides and sulfides. The seafood industry is concerned with the economic losses caused by bad appearance of the containers and the loss of nutritional properties of sardine and tuna.

\subsection{Deterioration of steel cans}

Levels of humidity and temperature bigger than $75 \%$ and $35{ }^{\circ} \mathrm{C}$ accelerated the CR. In summer the $\mathrm{CR}$ was higher after one year. For temperatures in the range from $25^{\circ} \mathrm{C}$ to $35^{\circ} \mathrm{C}$, and $\mathrm{RH}$ level of $35 \%$ to $75 \%$, the CR was very high. Furthermore, in winter, at temperatures around $10{ }^{\circ} \mathrm{C}$ to $20{ }^{\circ} \mathrm{C}$ and $\mathrm{RH}$ levels from $25 \%$ to $85 \%$, water condensates on the metal surface and the CR increases very fast. Variations of $\mathrm{RH}$ in the range from $25 \%$ to $75 \%$ and temperatures from $5{ }^{\circ} \mathrm{C}$ to $30{ }^{\circ} \mathrm{C}$, and the concentration levels of air pollutants such as sulfides and chlorides, which exceeds the permitted levels of the air quality standard (AQS), increase the corrosion process. In the autumn and winter, corrosion is generated by a film formed uniformly on the steels (Lopez et al, 2010). Exposition to $\mathrm{SO}_{2}$ indicates more damage, compared with the effect of the chlorides on the steel surface. The maximum CR representing the deterioration with steel exposed to $\mathrm{SO}_{2}$ was in winter for the high concentration levels of $\mathrm{RH}$ and the minimum was in spring. The major effect of $\mathrm{Cl}^{-}$on the deterioration of metallic surface occurred in winter and the minimum was in spring, same with the exposition of $\mathrm{SO}_{2}$ (Table 4).

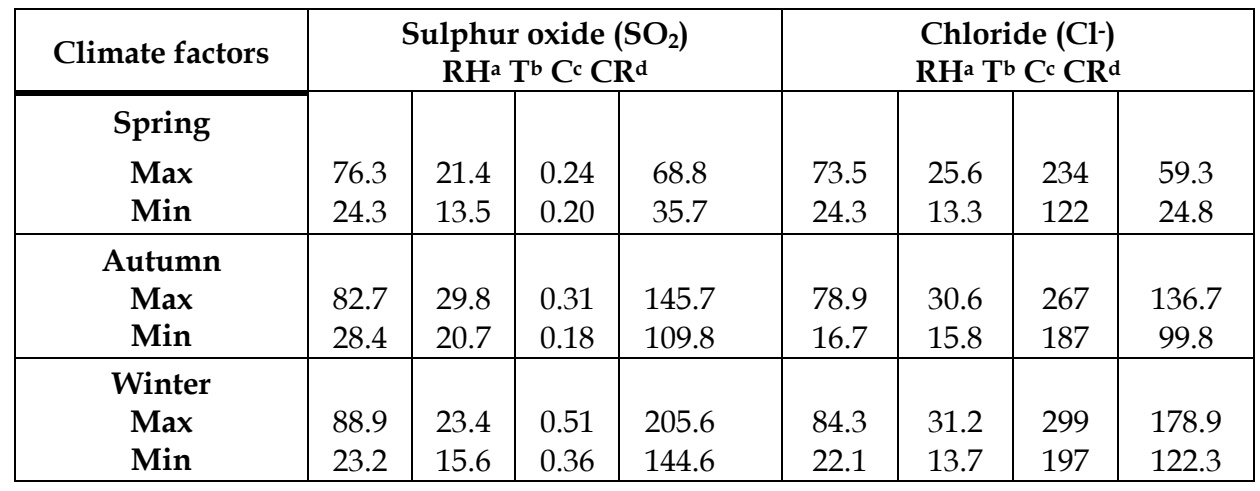

[a] RH. Relative Humidity (\%), [b] T. Temperature $\left({ }^{\circ} \mathrm{C}\right),[\mathrm{c}] \mathrm{C}$. Concentration Level of Air Pollutant (ppm), [d] CR- Corrosion rate (mg/m2.year).; Source. TPS and WCM.

Table 4. Effect of RH, temperature and air pollutants on the CR of steel (2010) 


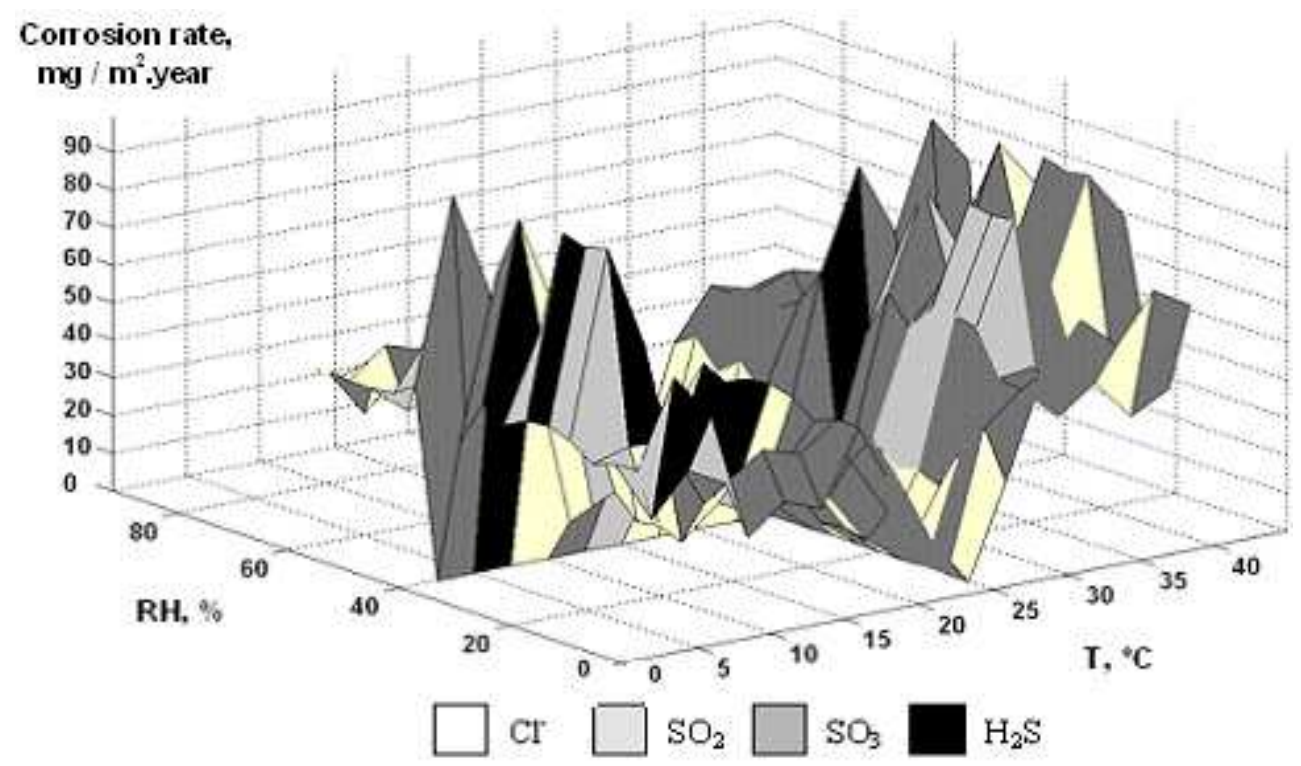

Fig. 3. CL of steel during summer exposition in Ensenada.

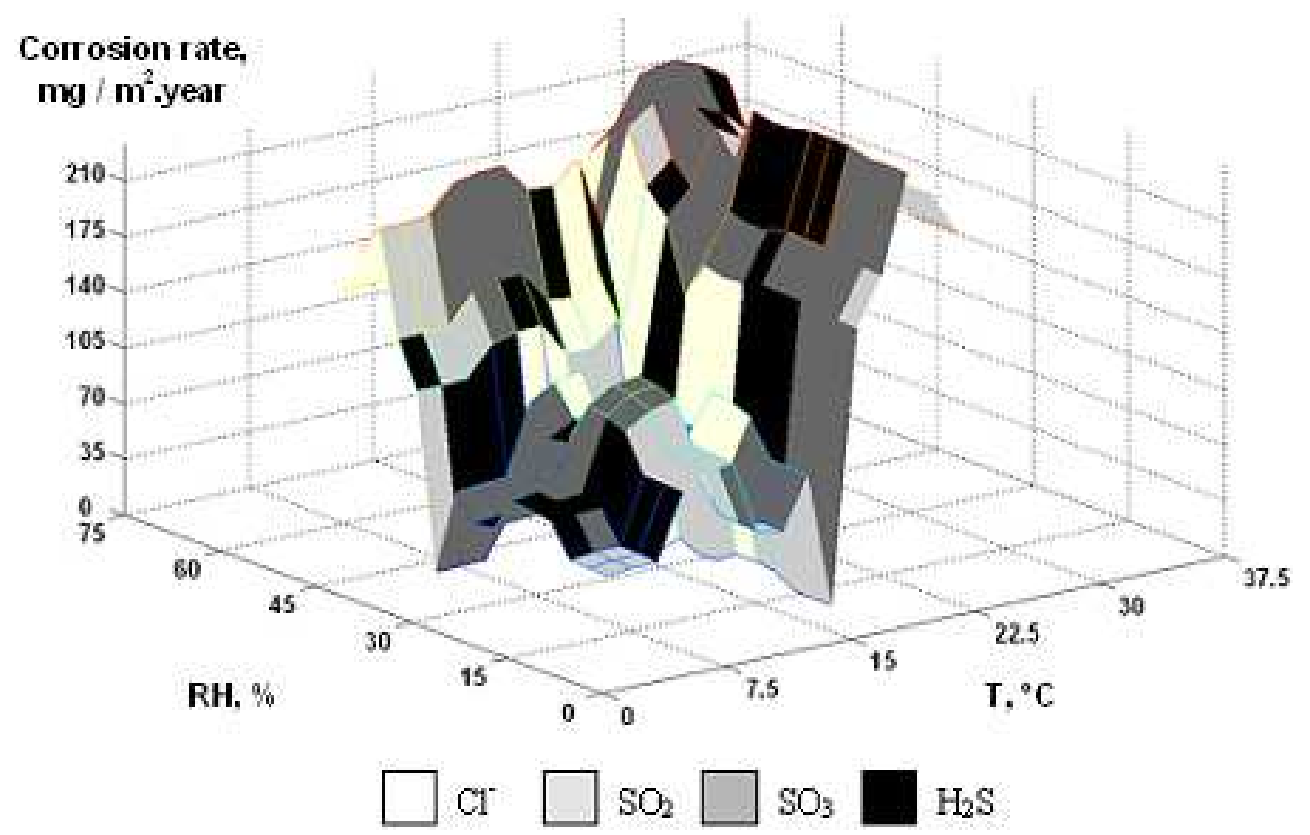

Fig. 4. CL of steel during winter exposition in Ensenada. 


\subsection{Corrosivity analysis}

A computer model of atmospheric corrosion has been used to simulate the steel exposed to air pollutants: $\mathrm{Cl}-, \mathrm{SO}_{2}, \mathrm{NO}_{2}, \mathrm{O}_{3}$ and $\mathrm{H}_{2} \mathrm{~S}$ from a thermoelectric station located between Tijuana and Ensenada. RH was correlated with the major $\mathrm{CR}$ was $35 \%$ to $55 \%$ with temperatures of $20^{\circ} \mathrm{C}$ to $30^{\circ} \mathrm{C}$. In summer $\mathrm{CR}$ was different than in winter, and in both environments (Figures 3 and 4). Air pollutants such as $\mathrm{Cl}^{-}, \mathrm{NO}_{2}$ and sulfide penetrate through defects of the air conditioning systems. Figure 3 shows the $\mathrm{CL}$ analysis of indoors in summer, indicating the level 1, as the major aggressive environment and levels 4 the low aggressiveness grade which generate high deterioration grade of this type of materials. Some sections of the Figure 4, represents the different grades of aggressiveness, with high areas of level 1 and 2 but levels 3 and 4 exists in less percentage. $\mathrm{RH}$ and temperature ranges were from $25 \%$ to $80 \%$ and $20^{\circ} \mathrm{C}$ to $30^{\circ} \mathrm{C}$ with $\mathrm{CR}$ from $30 \mathrm{mg} / \mathrm{m}^{2}$.year to $100 \mathrm{mg} / \mathrm{m}^{2}$.year with $\mathrm{RH}$ and temperatures from $40 \%$ a $75 \%$ and $20^{\circ} \mathrm{C}$ to $35^{\circ} \mathrm{C}$, with $\mathrm{CR}$ from 10 to $160 \mathrm{mg} / \mathrm{m}^{2}$.year.

\subsection{SEM analysis}

The steel samples of 1, 3, 6 and 12 months show localized corrosion with small spots during the summer period and more corroded areas with uniform corrosion in the winter. Air pollutants that react with steel surface form corrosion products, in some zones of steel cans and rolls with chloride ions (light color) and other with sulfides (dark color), as shown in the AES analysis. Some corrosion products in the internal of steel cans appeared on the surface contaminating the sardine (Figures 5 and 6). Various microorganisms and microbial metabolites are human pathogens in sardine and tuna conserved in steel cans were detected (Figures 7 and 8). According to the most common source of these organisms, they can be grouped as follows:

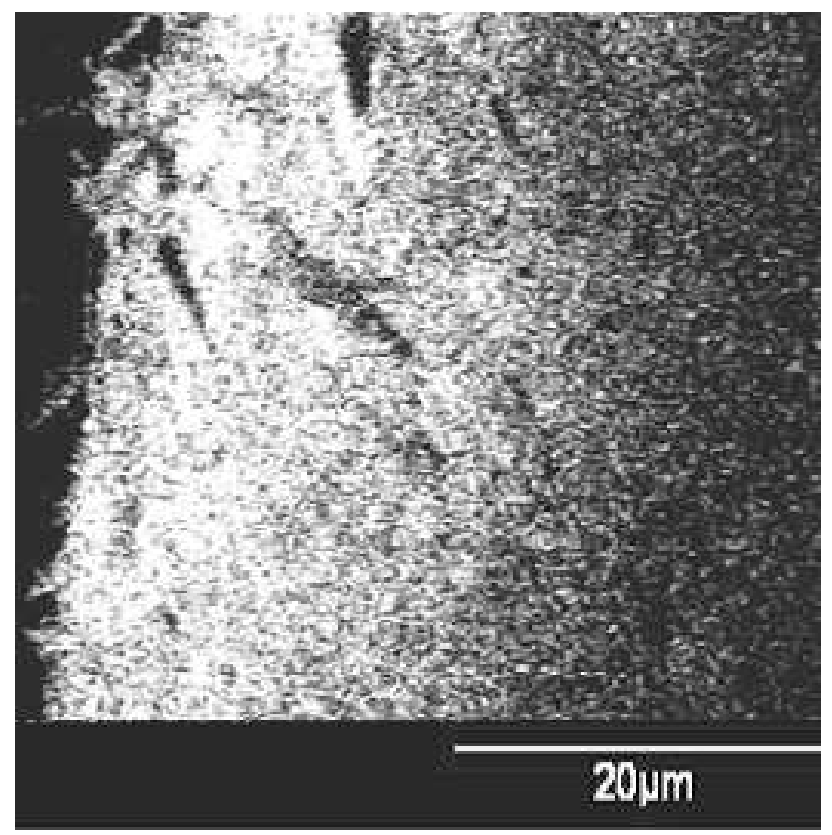

Fig. 5. Sardine contaminate with tin plate steel corrosion products. 


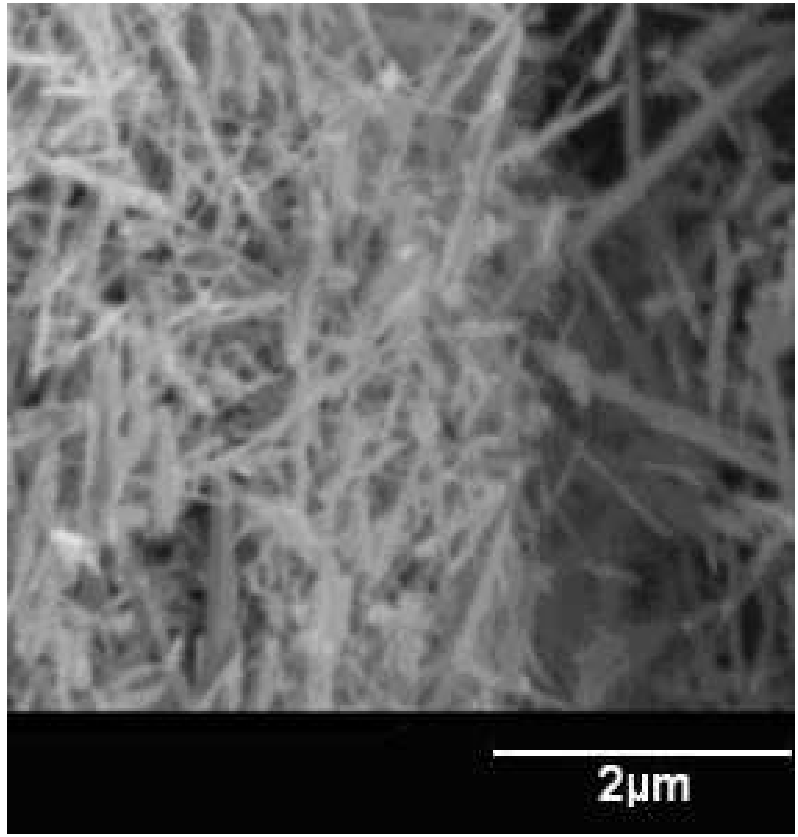

Fig. 6. Filiform corrosion formed in internal of tin plate steel cans

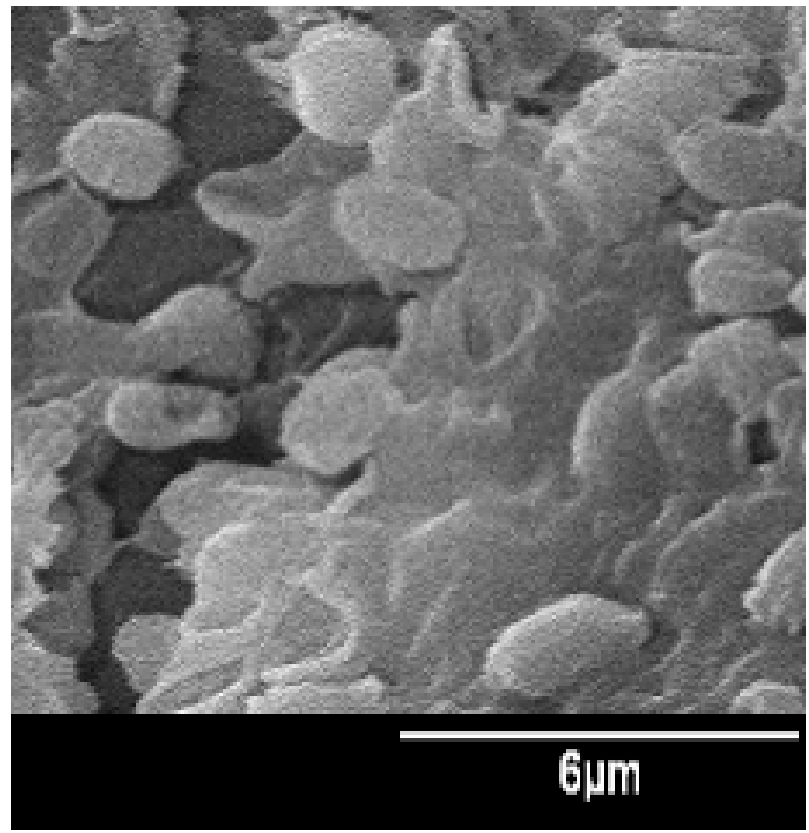

Fig. 7. Microbiological corrosion in internal of steel cans with plastic coatings. 


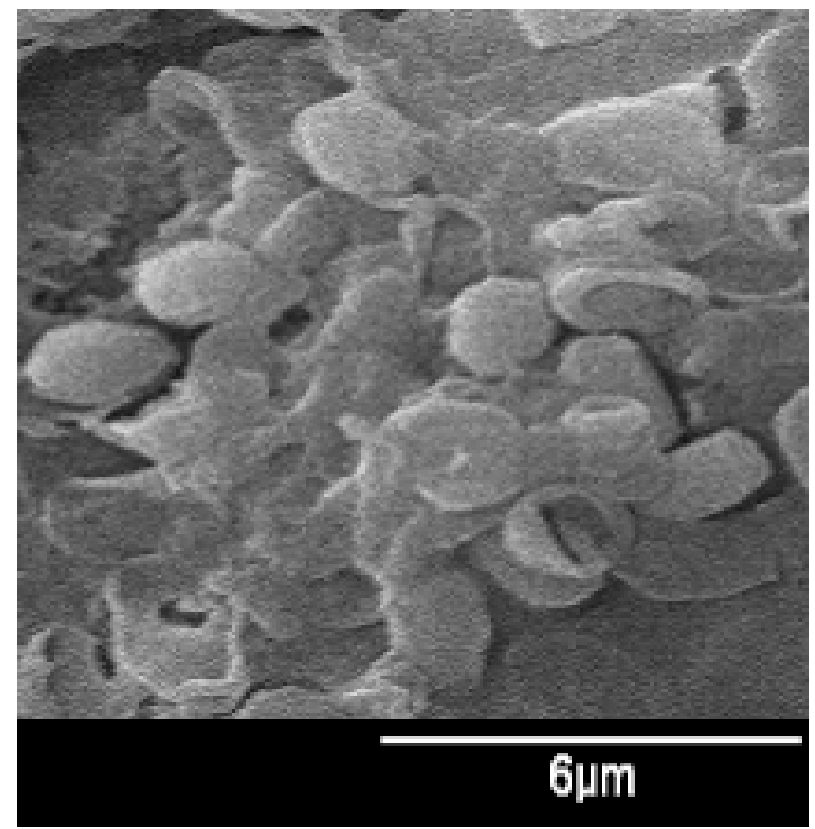

Fig. 8. Microbiological corrosion in internal of steel cans with tin coatings.

1. Endogenous. Originally present in the food before collection, including food animal, which produces the zoonoses diseases, transmitted from animals to humans in various ways, including through the digestive tract through food.

2. Exogenous. Do not exist in the food at the time of collection, at least in their internal structures, but came from the environment during production, transportation, storage, industrialization. Fungi are uni-or multicellular eukaryotic type, their most characteristic form is a mycelium or thallus and hyphae that are like branches.

\subsection{AES examination}

AES analyses were carried out to determine the corrosion products formed in indoor and outdoor of the steel cans. Figure 9a show scanning electron micrograph (SEM) images of areas selected for AES analysis covered by the principal corrosion products which are rich in chlorides and sulfides in tin plate steel cans evaluated. The Auger map process was performed to analyze punctual zones, indicating the presence of $\mathrm{Cl}^{-}$and $\mathrm{S}^{2-}$ as the main corrosive ions present in the steel corrosion products. The Auger spectra of steel cans was generated using a $5 \mathrm{keV}$ electron beam (Clark et al, 2006), which shows an analysis of the chemical composition of thin films formed in the steel surface (Figure 9b). The AES spectra of steel cans in the seafood plants show the surface analysis of two points evaluated in different zones of the steel probes. The peaks of steel appear between 700 and $705 \mathrm{eV}$, finding the chlorides and sulfides. In figure 10, the spectra reveals the same process as in figure 9 wit plastic coatings, with variable concentration in the chemical composition. In the two regions analyzed, where the principal pollutant was $\mathrm{Cl}^{-}$ion. In the region of steel surface were observed different concentrations of sulfide, carbon and oxygen, with low levels concentrations of $\mathrm{H}_{2} \mathrm{~S}$, which damage the steel surface. 
The standard thickness of $300 \mathrm{~nm}$ of tin plate and plastic coatings of internal and external of steel cans was determined by the AES technique with the sputtering process.

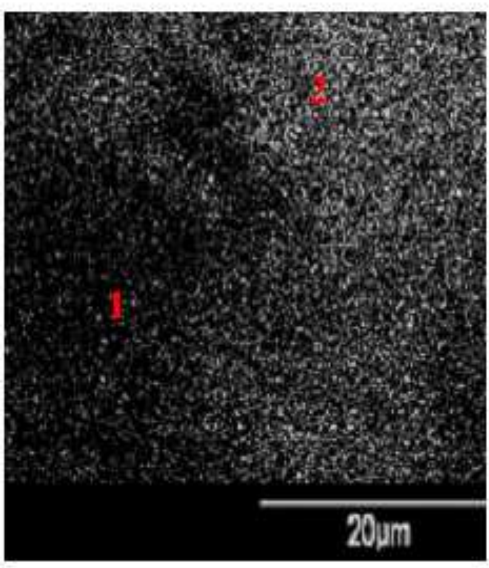

(a)

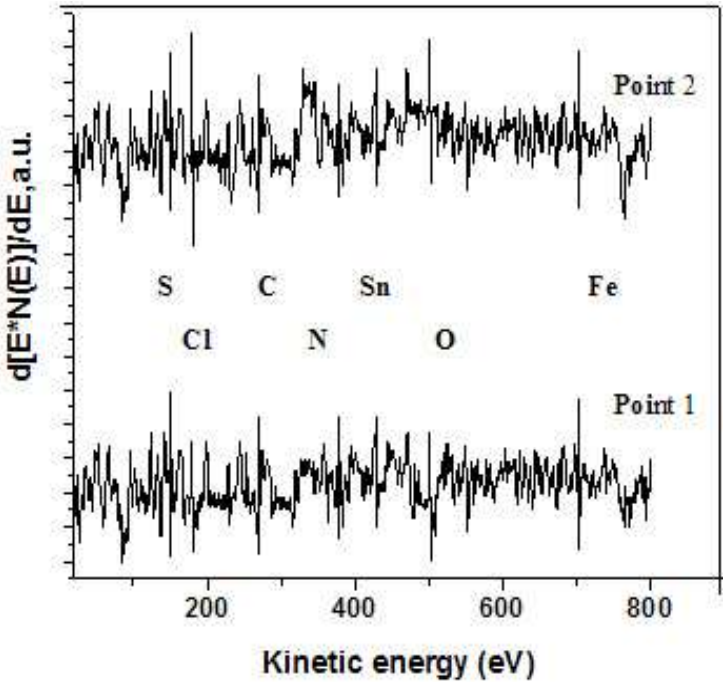

(b)

Fig. 9. Corrosion products of tin plated steel: (a) SEM microphotograph and (b) AES analysis, three months exposure.

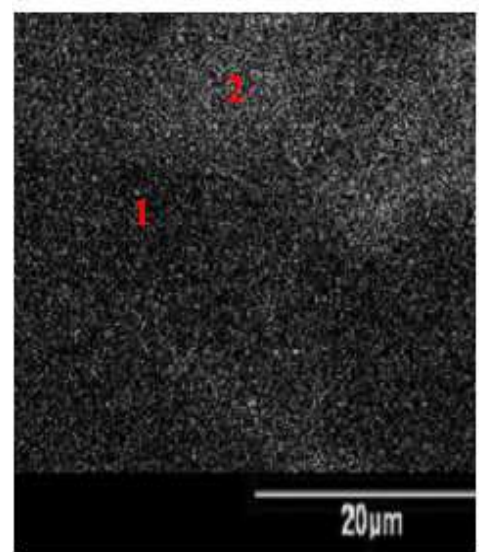

(a)

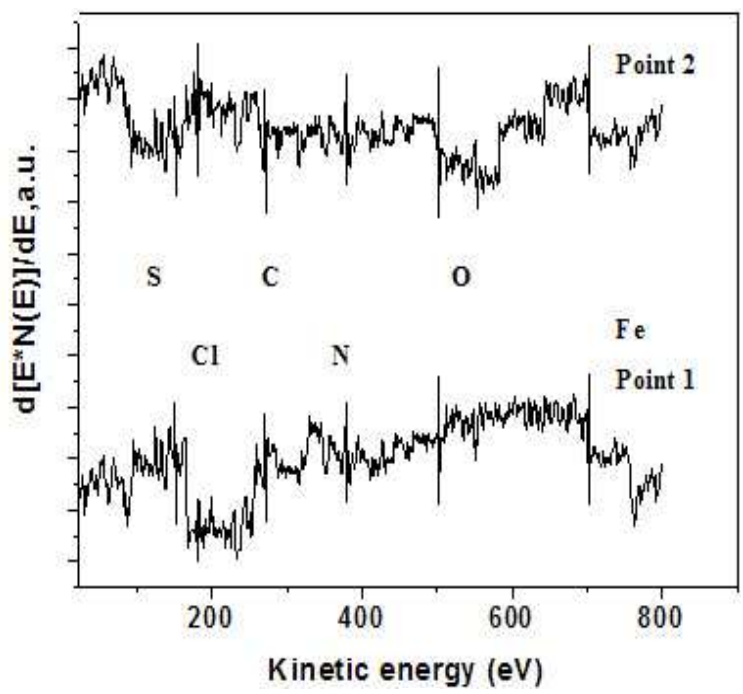

(b)

Fig. 10. Corrosion products of plastic coatings: (a) SEM microphotograph and (b) AES analysis, three months exposure. 


\section{Conclusions}

Corrosion is the general cause of the destruction of most of engineering materials; this destructive force has always existed. The development of thermoelectric industries, which generates electricity and the increased vehicular traffic, has changed the composition of the atmosphere of industrial centers and large urban centers, making it more corrosive. Steel production and improved mechanical properties have made it a very useful material, along with these improvements, but still, it is with great economic losses, because $25 \%$ of annual world steel production is destroyed by corrosion. The corrosion of metals is one of the greatest economic losses of modern civilization. Steel used in the cannery industry for seafood suffer from corrosion. The majority of seafood industries in Mexico are on the coast, such as Ensenada, where chloride and sulfide ions are the most aggressive agents that promote the corrosion process in the steel cans The air pollutants mentioned come from traffic vehicles and from the thermoelectric industry, located around $50 \mathrm{kms}$ from Ensenada. Plastic coatings are better than tin coating because, on the plastic coatings do not develop microorganisms and do not damage on the internal surface.

\section{References}

AHRAE; Handbook; Heating, Ventilating and Ari-Conditioning; applications; American Society of Heating, Refrigerating and Air-Conditioning Engineers Inc.; 1999.

Altos Hornos de Mexico, Acero AHMSA para la industria petrolera y de construccion; www.ahmsa.com, consulted, may 2011.

Annual Book of ASTM Standards, 2000, Wear and Erosion: Metal Corrosion, Vol. 03.02.

Asami K., Kikuchi M. and Hashimoto K.; An auger electron spectroscopic study of the corrosion behavior of an amorphous $\mathrm{Zr}_{40} \mathrm{Cu}_{60}$ alloy; Corrosion Science; Volume 39, Issue 1, January 1997, Pages 95-106; 1997.

ASTM G140-02; Standard Test Method for Determining Atmospheric Chloride Deposition Rate by Wet Candle Method; 2008.

ASTM G91-97; Standard Practice for Monitoring Atmospheric SO2 Using the Sulfation Plate Technique (SPT); 2010.

Avella M, De Vlieger JJ, Errico ME, Fischer S, Vacca P, Volpe MG.; Biodegradable starch/clay nanocomposite films for food packaging applications. Food Chem; 93(3):467-74; 2005.

BANCOMEXT, Datos de producción pesquera en México;

Brody A, Strupinsky ER, Kline LR. Odor removers. In: Brody A, Strupinsky ER, Kline LR, editors. Active packaging for food applications. Lancaster, Pa.: Technomic Publishing Company, Inc. p 107-17; 2001.

Brody Aaron L., Bugusu Betty, Han Jung h., Sand Koelsh, Mchugh Tara H.; Innovative Food Packing Solutions; Journal of Food Science; 2008.

Brown H, Williams; Packaged product quality and shelf life. In: Coles R, McDowell D, Kirwan MJ, editors. Food packaging technology. Oxford, U.K.: Blackwell Publishing Ltd. p 65-94; 2003.

Canning Green Beans (CGB); Ecoprofile of Truitt Brothers Process; Institute for Environmental Research and Education; 2007. 
Clark A. E., Pantan C. G, Hench L. L; Auger Spectroscopic Analysis of Bioglass Corrosion Films; Journal of the American Ceramic Society; Volume 59 Issue 1-2, Pages 37-39; 2006.

Cooksey K.; Effectiveness of antimicrobial food packaging materials. Food Addit Contam 22(10):980-7; 2005.

Doyle ME. ; Nanotechnology: a brief literature review. Food Research Institute Briefings [Internet]; http://www.wisc.edu/ fri/briefs/FRIBrief Nanotech Lit Rev.pdf; 2006.

FAO, Corporate Repository Report; consulted in

Finkenzeller K.; RFID handbook: fundamentals and applications. 2nd ed. West Sussex, U.K.: JohnWiley \& Sons Ltd. 452 p.; 2003.

http://www.fao.org/documents/en/Fisheries\%20and\%20aquaculture\%20manage ment\%20and\%20conservation/topicsearch/3, 2011.

http://www.financierarural.gob.mx/informacionsectorrural/Documents/Sector\% 20pesquero/SectorPesqueroM\%C3\%A9xicoFR07.pdf, consulted, june 2011.

Ibars JR, Moreno DA, Ranninger C.; Microbial corrosion of stainless steel; Microbiologia. Nov;8(2):63-75; 1992.

ISO 11844-1:2006. Corrosion of metals and alloys - Classification of low corrosivity of indoor atmospheres- Determination and estimation of indoor corrosivity. ISO, Geneva, 2006.

ISO 11844-2:2005. Corrosion of metals and alloys - Classification of low corrosivity of indoor atmospheres - Determination and estimation attack in indoor atmospheres. ISO, Geneva, 2005.

ISO 9223:1992, Corrosion of metals and alloys, Corrosivity of Atmospheres, Classification.

Lange J, Wyser Y.; Recent innovations in barrier technologies for plastic packaging-a review. Packag Technol Sci 16:149-58.; 2003.

Lopez B. Gustavo, Valdez S. Benjamin, Schorr W. Miguel, Zlatev R., Tiznado V. Hugo, Soto H. Gerardo, De la Cruz W.; AES in corrosion of electronic devices in arid in marine environments; AntiCorrosion Methods and Materials; 2011.

Lopez B.G.; Ph.D. Thesis; Caracterización de la corrosión en materiales metálicos de la industria electrónica en Mexicali, B.C., 2008 (Spanish).

Lopez B.G.; Valdez S. B.; Schorr M. W.; "Spectroscopy analysis of corrosion in the electronic industry influeced by Santa Ana winds in marine environments of Mexico"; INTECH Ed. INDOOR AND OUTDOOR POLLUTON, 4; Edited by Jose A. Orosa, Book, 2011.

Lord JB.; The food industry in the United States. In: Brody AL, Lord J, editors. Developing new food products for a changing market place. 2nd ed. Boca Raton, Fla.: CRS Press. p 1-23; 2008.

Moncmanova A. Ed. ; Environmental Deterioration of Materials, WITPress, pp 108-112; 2007.

Nachay K. ; Analyzing nanotechnology. Food Tech 61(1):34-6; 2007.

Ray S, Easteal A, Quek SY, Chen XD; The potential use of polymer-clay nanocomposites in food packaging. Int J Food Eng 2(4):1-11; 2006

Soroka, W, "Fundamentals of Packaging Technology", Institute of Packaging Professionals (IoPP), ISBN 1-930268-25-4; 2002.

Walsh, Azarm, Balachandran, Magrab, Herold \& Duncan Engineers Guide to MATLAB, Prentice Hall, 2010, ISBN-10: 0131991108. 
Weiss J, Takhistov P, McClements J.; Functional materials in food nanotechnology; J. Food Science; 71(9):R107-16; 2006.

Yam KL, Takhistov PT,Miltz J.; Intelligent packaging: concepts and applications; J Food Sci 70(1):R1-10; 2005. 
SCIENTIFIC, HEALTH

AND SOCIAL ASPECTS

OF THE FOOD

INDUSTRY

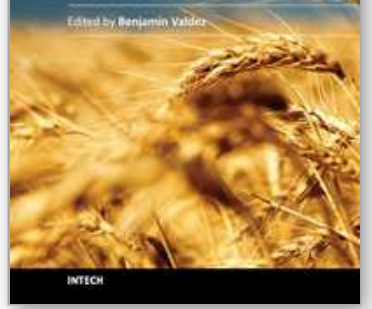

Scientific, Health and Social Aspects of the Food Industry

Edited by Dr. Benjamin Valdez

ISBN 978-953-307-916-5

Hard cover, 488 pages

Publisher InTech

Published online 01, February, 2012

Published in print edition February, 2012

This book presents the wisdom, knowledge and expertise of the food industry that ensures the supply of food to maintain the health, comfort, and wellbeing of humankind. The global food industry has the largest market: the world population of seven billion people. The book pioneers life-saving innovations and assists in the fight against world hunger and food shortages that threaten human essentials such as water and energy supply. Floods, droughts, fires, storms, climate change, global warming and greenhouse gas emissions can be devastating, altering the environment and, ultimately, the production of foods. Experts from industry and academia, as well as food producers, designers of food processing equipment, and corrosion practitioners have written special chapters for this rich compendium based on their encyclopedic knowledge and practical experience. This is a multi-authored book. The writers, who come from diverse areas of food science and technology, enrich this volume by presenting different approaches and orientations.

\section{How to reference}

In order to correctly reference this scholarly work, feel free to copy and paste the following:

Gustavo Lopez Badilla, Benjamin Valdez Salas and Michael Schorr Wiener (2012). Micro and Nano Corrosion in Steel Cans Used in the Seafood Industry, Scientific, Health and Social Aspects of the Food Industry, Dr. Benjamin Valdez (Ed.), ISBN: 978-953-307-916-5, InTech, Available from:

http://www.intechopen.com/books/scientific-health-and-social-aspects-of-the-food-industry/micro-and-nanocorrosion-in-steel-cans-used-in-the-seafood-industry

\section{INTECH}

open science | open minds

\section{InTech Europe}

University Campus STeP Ri

Slavka Krautzeka 83/A

51000 Rijeka, Croatia

Phone: +385 (51) 770447

Fax: +385 (51) 686166

www.intechopen.com

\section{InTech China}

Unit 405, Office Block, Hotel Equatorial Shanghai

No.65, Yan An Road (West), Shanghai, 200040, China

中国上海市延安西路65号上海国际贵都大饭店办公楼405单元

Phone: +86-21-62489820

Fax: $+86-21-62489821$ 
(C) 2012 The Author(s). Licensee IntechOpen. This is an open access article distributed under the terms of the Creative Commons Attribution 3.0 License, which permits unrestricted use, distribution, and reproduction in any medium, provided the original work is properly cited. 